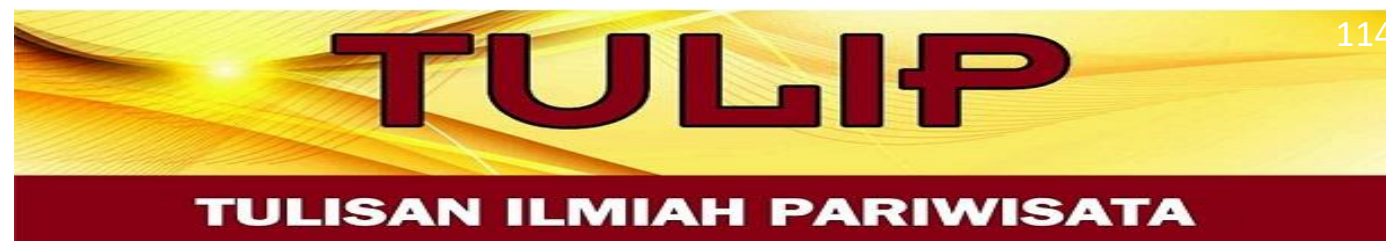

\title{
EVALUASI KETERPENGARUHAN KOMPONEN PERIWISATA DI DAYA TARIK PARIWISATA ARUNG JERAM PAPUALANGI
}

\author{
Srilian Laxmiwaty Dai \\ sriliandai@gmail.com \\ Dosen Pariwisata, FIB_UMGo, Jl.Prof Mansoer Pateda, Indonesia \\ Deswita Natarisa Mamonto \\ deswitanatarisa@gmail.com, \\ Wahawiswa, Pariwisata, FIB_UMGo, JI.Prof Mansoer Pateda, Indonesia
}

\begin{abstract}
Abstrak
Dalam penelitian tentang Evaluasi Keterpengaruhan Komponen Pariwisata Didaya Tarik Pariwisata Arung Jeram Papualangi penulis menggunakan pendekatan kualitatif dimana penelitian yang dilakukan bersifat deskriptif yaitu memberikan gambaran ataupun penjelasan yang tepat mengenai permasalahan yang dihadapi dan didukung dengan data primer dan data sekunder. Teknik pengumpulan data yang digunakan adalah wawancara dan observasi. Dari hasil penelitian menunjukkan bahwa pada pelaksanaan Evaluasi Keterpengaruhan Komponen Pariwisata Didaya Tarik Pariwisata Arung Jeram Papualangi telah berjalan sesuai dengan sistem yang ada, namun terdapat masalah-masalah yang membawa dampak negatif sehingga pada pelaksanaannya masih belum optimal dalam mengembangkan pariwisata Tana Toraja, khususnya pembangunan infrastruktur, sarana dan prasana. Faktor yang mempengaruhi perkembangan pariwisata adalah faktor pendukung yaitu objek wisata yang sudah terkenal, partisipasi masyarakat dan koordinasi yang baik dengan pihak terkait. Sedangkan faktor penghambat yaitu keterbatasan dana, lokasi geografis objek wisata serta minimnya dan tidak terpusatnya informasi.
\end{abstract}

Kata Kunci : Evaluasi Program, Pengembangan, Komponen Wisata

Available Online at http://journal.umgo.ac.id/index.php/Tulip

TULIP: Tulisan Ilmiah Pariwisata, Vol. 2, No. 2 Desember 2019, 114-129 


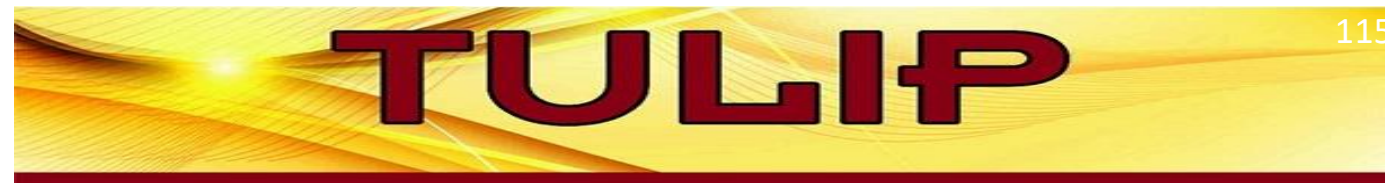

\section{TULISAN ILMIAH PARIVISATA}

\section{PENDAHULUAN}

Pembangunan nasional dilaksanakan secara merata diseluruh tanah air dan tidak hanya untuk satu golongan atau sebagian masyarakat, tetapi harus benarbenar dapat dirasakan oleh seluruh rakyat sebagai bagian untuk memperbaiki tingkat hidup yang berkeadilan sosial yang menjadi tujuan dan cita- cita kemerdekaan bangsa indonesia. Proses pembangunan terjadi dalam semua aspek kehidupan, baik yang berlangsung pada tingkat nasional maupun wilayah/daerah. "Jalan" menuju tingkat kesejahteraan masyarakat yang lebih tinggi sungguh beraneka ragam. Ada jalur politik, jalur ekonomi, jalur pendidikan, jalur hukum dan lain sebagainya. Meskipun benar bahwa tidak semua "jalur" tersebut harus ditempuh hanya oleh pemerintah, karena masyarakat pun mutlak perlu ikut berperan serta, pemerintah tetap memainkan peranannya yang sangat penting. Peranan tersebut pada umumnya muncul dalam berbagai bentuk seperti fungsi pengaturan, fungsi perumusan berbagai jenis kebijaksanaan, fungsi pelayanan, fungsi penegakan hukum, serta fungsi pemeliharaan ketertiban umum dan keamanan. Agar peranan dan berbagai fungsi tersebut terselenggara dengan baik, mutlak diperlukan keabsahan pemerintah yang bersangkutan (Siagian, 2007).

Banyak kegiatan pembangunan yang harus dilakukan oleh pemerintah, setidak-tidaknya pada tahap awal pembangunan. Karakteristik yang cukup penting dalam pembangunan adalah adanya kemajuan/perbaikan dan pertumbuhan. Yang paling utama adalah pembangunan prasarana dasar, baik prasarana ekonomi maupun sosial. Prasarana ekonomi meliputi perhubungan dan transportasi, energi, irigasi dan sebagainya. Prasarana sosial mencakup prasarana pendidikan seperti sekolah-sekolah dan prasarana kesehatan seperti rumah sakit. Di samping prasarana fisik, pemerintah juga perlu memperhatikan pembangunan lembagalembaga sosial, baik lembaga politik, hukum, budaya maupun ekonomi. Dalam proses pembangunan nasional di dahului oleh adanya suatu perencanaan yang dilakukan dengan suatu cara tertentu. Perencanaan adalah suatu proses untuk menentukan tindakan masa depan yang tepat melalui urutan pilihan, dengan

Available Online at http: //journal.umgo.ac.id/index.php/Tulip 


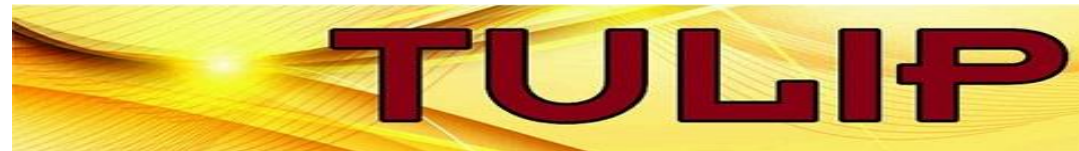

\section{TULISAN ILMIAH PARIMISATA}

memperhitungkan sumber daya yang tersedia. Perencanaan pembangunan nasional disusun secara sistematis, terarah, terpadu, menyeluruh dan tanggap terhadap perubahan. Perencanaan pembangunan nasional menghasilkan rencana pembangunan jangka panjang, rencana pembangunan jangka menengah dan rencana pembangunan jangka pendek. Tahapan perencanaan pembangunan nasioanl meliputi penyusunan rencana, penetapan rencana, pengendalian pelaksanaan rencana dan evaluasi pelaksanaan rencana (Ginanjar, 1997).

Pelaksanaan adalah suatu proses rangkaian kegiatan tindak lanjut setelah sebuah rencana ditetapkan yang terdiri atas pengambilan keputusan, langkahlangkah yang strategi maupun yang oprasional yang ditempuh guna mewujudkan suatu kegiatan menjadi kenyataan guna mencapai sasaran dari program yang ditetapkan semula. Dalam pelaksanaan suatu program pembangunan dapat dilakukan sendiri atau kerjasama antara pemerintah pusat dan daerah. Untuk itu perlu ada mobilisasi tenaga serta kesiapan lembaga

pemerintah dalam pelaksanaan program pembangunan. Salah satu sektor penting pembangunan di indonesia adalah pembangunan di bidang pariwisata.

Dalam era globalisasi saat ini, sektor pariwisata merupakan industri terbesar dan terkuat dalam pembiayaan ekonomi global, pariwisata telah memberikan devisa yang cukup besar bagi berbagai negara. Pariwisata sebagai suatu sektor kehidupan, telah mengambil peran penting dalam pembangunan perekonomian bangsa-bangsa di dunia, yang ditunjukkan dengan meningkatnya kesejahteraan ekonomi bangsa-bangsa di dunia yang semakin baik dan maju. Kemajuan dan kesejahteraan yang makin tinggi dan telah menjadikan pariwisata sebagai bagian pokok dari kebutuhan atau gaya hidup manusia, dan menggerakkan jutaan manusia untuk mengenal alam dan budaya ke belahan atau kawasan-kawasan dunia lainnya. Pergerakan jutaan manusia selanjutnya menggerakkan mata rantai ekonomi yang saling berkaitan menjadi industri jasa yang memberikan kontribusi penting bagi perekonomian dunia, perekonomian bangsa-bangsa, hingga peningkatan kesejahteraan ekonomi di tingkat masyarakat 


\section{TULISAN ILMIAH PARIMISATA}

lokal. Sementara itu, dari perspektif pembangunan sumber daya manusia, pariwisata mempunyai potensi untuk dijadikan instrumen dalam meningkatkan kualitas hidup masyarakat, khususnya penduduk sekitar Destinasi Pariwisata. Dengan demikian, pariwisata dapat meningkatkan kesejahteraan masyarakat, bukan saja kesejahteraan material dan spiritual, tetapi juga sekaligus meningkatkan kesejahteraan kultural dan intelektual. Ditilik dari perspektif bangsa yang lebih luas, pariwisata mempunyai potensi yang jauh lebih besar dan juga lebih mulia, yaitu dapat meningkatkan kualitas hubungan antarmanusia dan antarbangsa sehingga terjalin saling pengertian yang lebih baik, sikap saling menghargai, persahabatan, solidaritas, bahkan perdamaian.

Di Indonesia, pembangunan pariwisata juga memiliki kontribusi yang signifikan dalam pembangunan ekonomi nasional sebagai instrumen peningkatan perolehan devisa maupun lapangan kerja. Sektor pariwisata juga membawa dampak sosial, ekonomi, maupun dalam konteks pelestarian dan pengelolaan lingkungan, sumber daya alam, dan budaya yang semakin arif dan bijaksana. Prospek yang sangat strategis pada sektor pariwisata tersebut tentu menjadi peluang yang sangat berarti bagi indonesia sebagai suatu negara yang memiliki kekayaan alam dan budaya yang sangat besar yang membentang dan tersebar di lebih dari 17.000 (tujuh belas ribu) pulau. Sektor pariwisata yang telah berperan sebagai penyumbang devisa tersebar kedua setelas migas, menjadi industri atau sektor penting yang dapat di andalkan pemerintah kedepan untuk menjadi pilar utama pembangunan ekonomi nasional (Nugroho, 2011). Dalam konteks tersebut, maka pengembangan sektor pariwisata harus digarap secara serius, terarah, dan profesional agar pengembangan dan pemanfaatan aset-aset pariwisata dapat memberi kontribusi signifikan dalam mewujudkan peran sektor pariwisata sebagai sektor andalan dalam pembangunan di masa depan.

\section{METODE PENELITIAN}

Dalam artikel ini, teori yang digunakan adalah teori Eksistensi yang secara etiomologi melahirkan kata Eksistensialisme, yang merupakan bahasa latin

Available Online at http: //journal.umgo.ac.id/index.php/Tulip 


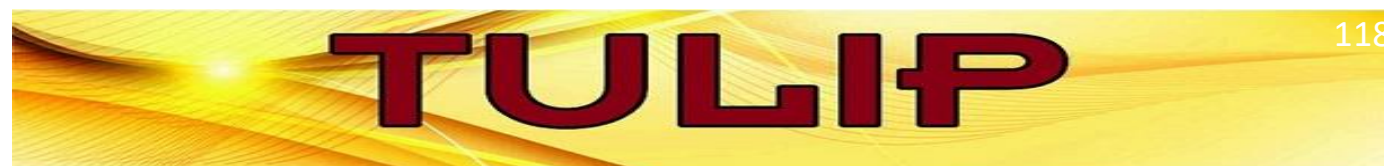

\section{TULISAN ILMIAH PARIMISATA}

existere dengan makna muncul, ada, timbul, memilih keberadaan aktual. Untuk itu eksistensialisme didefinisikan sebagai gerakan filsafat yang menentang esensialisme. Kata eksistensi berasal dari kata Latin Existere, dari ex keluar sitere membuat berdiri. Artinya apa yang ada, apa yang memiliki aktualitas, apa yang dialami. Konsep ini menekankan bahwa sesuatu itu ada.

Dalam konsep eksistensi, satu-satunya faktor yang membedakan setiap hal yang ada dari tiada adalah fakta. Setiap hal yang ada itu mempunyai eksistensi atau ia adalah suatu eksisten. Dengan demikian menurut Bapak Gerakan Eksistensialis Kierkegaard, menegaskan bahwa yang pertama-tama penting bagi keadaan manusia yakni keadaannya sendiri atau eksistensinya sendiri. Ia menegaskan bahwa eksistensi manusia bukanlah 'ada' yang statis, melainkan 'ada' yang 'menjadi'. Dalam arti terjadi perpindahan dari 'kemungkinan' ke 'kenyataan. Apa yang semula berada sebagai kemungkinan berubah menjadi kenyataan. Gerak ini adalah perpindahan yang bebas, yang terjadi dalam kebebasan dank e luar dari kebebasan. Ini terjadi karena manusia mempunyai kebebasan memilih. Metode yang digunakan dalam artikel ini adalah deskriptif kualitatif dimana diharapkan dapat membantu pembaca untuk mengetahui berbagai aktivitas, realita, serta paradigma pemikiran yang berkembang, Emzir (2011:174)

\section{HASIL DAN PEMBAHASAN}

\section{Pengertian Evaluasi}

Sangat perlu untuk menentukan bagaimana program-program yang sesungguhnya berjalan, untuk mengukur hasil kondisi-kondisi pelaksanaan dan menyelidiki apakah program dilaksanakan sesuai dengan apa yang di inginkan dan apabila tidak, berada dalam posisi untuk menghentikan atau memperbaiki. Penyelidikan yang diperlukan ini disebut suatu evaluasi. Evaluasi dalam penggunaannya yang paling umum adalah suatu proses yang dilakukan untuk menetukan nilai (value). Evaluasi dianggap sebagai cara untuk menerapkan secara 


\section{TULISAN ILMIAH PARIMISATA}

sistematis ide pengujian eksperimental atas pilhan kebijakan dalam lingkungan yang terkontrol (Frank 2015).

Kebutuhan dan tuntutan akan pertanggungjawaban menimbulkan suatu kebutuhan dilakukannya evaluasi. Pertanggungjawaban tidak terbatas pada suatu aktivitas, akan tetapi juga untuk memperbaiki pelaksanaan program dan perkembangan masyarakat. Menurut Wirawan (2012) evaluasi adalah :

"Riset untuk mengumpulkan, menganalisis, dan menyajikan informasi yang bermanfaat mengenai objek evaluasi, menilainya dengan membandingkannya dengan indikator evaluasi dan hasilnya dipergunakan untuk mengambil keputusan mengenai objek evaluasi."

Rossi dan Freeman (dalam Wirawan, 2012) menyatakan mengenai evaluasi sebagai berikut :

"Evaluation research is a systematic application of sosial research prosedures in assessing the concepualization and design, implementation, and ulitily of social interventiation programs."

Menurut kedua pakar evaluasi tersebut evaluasi berkaitan dengan penelitian sosial mengenai konsepsialisasi dan pendisainan, implementasi dan pemanfaatan program intervensi sosial yang dilakukan oleh pemerintah.

Vendung (dalam Wirawan, 2012) menyatakan sebagai berikut :

"Evaluation is limited to governmen intervention only, that is, politically or administratively planned social change, like public policies, public programs, and public service."

Menurut Vendung, evaluasi berkaitan dengan intervensi pemerintah yaitu perubahan sosial politik dan administratif yang direncanakan misalnya kebijakan publik, program publik dan layanan publik. Evaluasi melihat kebelakang agar dapat menyetir kedepan. Evaluasi merupakan mekanisme untuk memonitor, mensistematikan, dan meningkatkan aktivitas pemerintah dan hasil-hasilnya sehingga pejabat publik dalam pekerjaanya di masa akan datang dapat bertindak serta bertanggungjawab, kreatif dan seefisien mungkin.

Sedangkan pandangan lain dari Wilyam N. Dunn,1999 (dalam Nugroho,2003) istilah evaluasi dapat disamakan dengan penaksiran (appraisal),

Available Online at http: //journal.umgo.ac.id/index.php/Tulip 


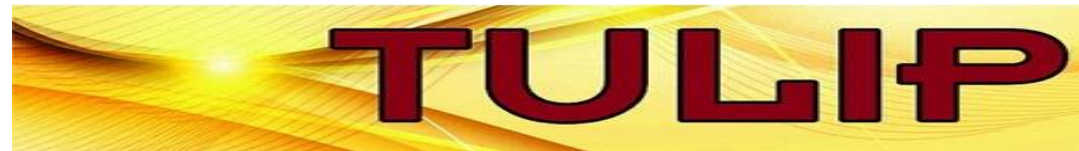

\section{TULISAN ILMIAH PARIMISATA}

pemberian angka (rating), dan penilaian (assesment). Evaluasi berkenan dengan produksi informasi mengenai nilai atau manfaat hasil kebijakan. Evaluasi memberi informasi yang valid dan dapat dipercaya mengenai kinerja kebijakan, yaitu seberapa jauh kebutuhan, nilai dan kesempatan telah dapat dicapai melalui tindakan publik; evaluasi memberi sumbangan pada klarifikasi dan kritik terhadap nilai-nilai yang mendasari pemilihan tujuan dan target; dan evaluasi memberi sumbangan pada aplikasi metode-metode analisis kebijakan lainnya, termasuk perumusan masalah dan rekomendasi.

Dalam buku Evaluasi Kinerja Perusahaan (Husein Umar, 2005) mendefinisikan Evaluasi sebagai berikut :

"Suatu proses untuk menyediakan informasi tentang sejauh mana suatu kegiatan tertentu telah dicapai, bagaimana perbedaan pencapaian itu dengan suatu stndar tertentu untuk mengetahui apakah ada selisih di antara keduanya , serta bagaimana manfaat yang telah dikerjakan itu dikerjakan itu bila dibandingkan dengan harapan-harapan yang ingin diperoleh. Evaluasi memungkinkan pelaksana suatu program untuk mengetahui hasil yang nyatanya dicapai. Penialian yang objektif, rasional dan berdasarkan kriteria yang telah ditetapkan sebelumnya dalam rencana akan diketahui apakah: hasil yang dicapai melebihi target dan standar yang telah ditentukan, hasil yang dicapai sekadar sesuai harapan, atau kurang dari yang ditentukan (dalam Arikunto, 2010)

Definisi evaluasi yang dituliskan dalam kamus Oxford Advanced Learner's Dictionary of Current English (AS Hornby:1986) di kutip dalam Arikunto 2010, evaluasi adalah to find out, decide the amount or value yang artinya suatu upaya untuk menentukan nilai atau jumlah. Selain arti berdasarkan terjemahan, kata- kata yang terkandung di dalam definisi tersebut pun menunjukkan bahwa kegiatan evaluasi harus dilakukan secara hati-hati, bertanggungjawab, menggunakan strategi, dan dapat dipertanggungjawabkan.

Suchman (Wirawan, 2012) mengaitkan evaluasi dengan konteks administrasi. Kesuksesan suatu program evaluasi sebagian besar tergantung pada kemanfaatannya bagi adminstrator dalam memperbaiki layanan dalam masyarakat. Suchman (Nugroho, 2003) juga memandang evaluasi sebagai sebuah 


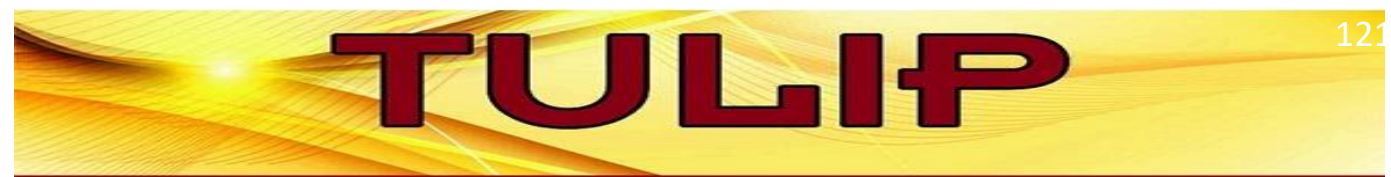

\section{TULISAN ILMIAH PARIMISATA}

proses menentukan hasil yang telah dicapai beberapa kegiatan yang telah direcanakan untuk mendukung tercapaianya tujuan.

Kepariwisataan Arung Jeram Papualangi

Papualangi memiliki potensi pariwisata yang begitu beragam, baik dari sisi produk wisata maupun pasar wisatawan. Dengan alam dan budaya yang dimiliki Papualangi sudah terkenal sebagai destinasi pariwisata yang bertaraf Internasional. Keindahan panorama alam, aset pusaka budaya yang unik, upacara pemakaman dan arsitek rumah Tongkonan menjadikan Papualangi dinominasikan sebagai salah satu situs dalam daftar World Heritage Culture oleh UNESCO di Indonesia.

\section{Sebaran Kawasan Pariwisata Arung Jeram Papualangi}

Kawasan Pariwisata ditujukan untuk meningkatkan daya saing destinasi wisata di Indonesia secara berkelanjutan dan terutama untuk memastikan partisipasi masyarakat dalam pembangunan kepariwisataan Indonesia. Pengertian Kawasan Pariwisata nasional dalam Rencana Induk Kepariwisataan Nasional (RIPPARNAS) adalah kawasan yang memiliki fungsi utama pariwisata nasional yang mempunyai pengaruh penting dalam satu atau lebih aspek, seperti pertumbuhan ekonomi, sosial, budaya, pemberdayaan sumber daya alam, daya dukung lingkungan hidup, serta pertahanan dan keamanan.

\section{Sebaran Potensi Obyek Wisata Papualangi}

Layaknya suatu objek wisata dapat dikembangkan apabila memiliki daya tarik, berdasarkan Keputusan Bupati penetapan objek dan daya tarik wisata di Papualangi, antara lain : Daftar objek wisata diatas merupakan daftar objek wisata yang telah mendapat izin operasional, namun tidak semuanya telah beroperasi secara maksimal karena masih dalam tahap pengerjaan. Hanya ada 9 yang saat ini telah beroperasi dengan baik dan banyak dikunjungi wisatawan dan memiliki sarana prasarana yang hampir lengkap, yaitu :

Program Pengembangan Pariwisata Kabupaten Gorontalo

Available Online at http: //journal.umgo.ac.id/index.php/Tulip 


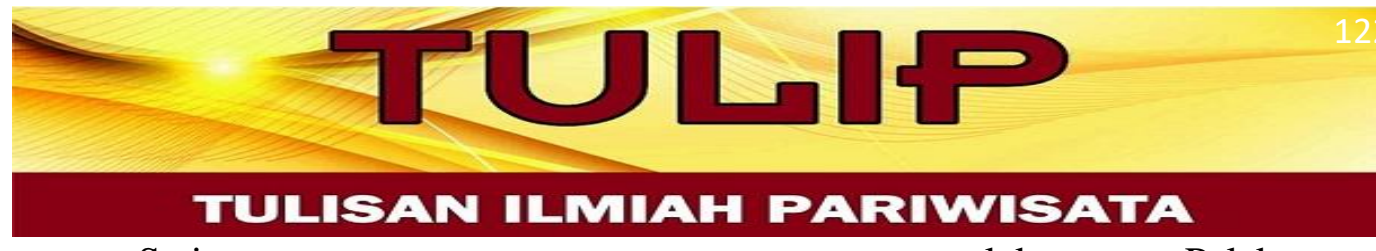

Setiap perumusan suatu program, menuntut pelaksanaan. Pelaksanaan suatu program yang telah ditetapkan harus sejalan dengan kondisi yang ada, yang mana dalam kegiatannya melibatkan beberapa unsur disertai dengan usaha-usaha dan didukung oleh alat-alat penunjang. Pelaksanaan suatu program adalah sesuatu yang menuntut kehati-hatian, dan bahkan pada saat penyusunannya. Pelaksanaan itu mencakup kegiatan dan tindakan.

Kondisi umum pariwisata di Papualangi saat ini masih jauh berbeda dengan daerah tujuan wisata yang ada di Indonesia, seperti bali dan daerah lainnya. Dengan memperhatikan perkembangan lingkungan strategik baik pada tingkat nasional dan regional yang semakin meningkatnya tuntutan masyarakat dalam penyelenggaraan pemerintahan dan pelaksanaan pembangunan daerah.

Kebudayaan merupakan bagian yang penting dalam proses pembangunan. Kebudayaan terkait dengan persoalan karakter dan mental bangsa yang menentukan keberhasilan pembangunan di Indonesia. Kebudayaan Indonesia berkaitan dengan keseluruhan sistem gagasan, tindakan, dan hasil karya masyarakat yang tinggal mendiami wilayah Indonesia. Kebudayaan Indonesia yang terbentuk dari ratusan budaya daerah memiliki karakteristik tersendiri. Ratusan adat istiadat, kesenian dan bahasa, suku bangsa yang berbeda-beda yang merupakan potensi untuk dikembangkan dalam proses pembangunan dan terutama untuk peningkatan kesejahteraan masyarakat. Hal ini tercantum dalam Visi Dinas Kebudayaan dan Pariwisata Papualangi.

Pembangunan Pariwisata di Papualangi merupakan salah satu fokus pemerintah. Agar pembangunan dan pengembangan pariwisata dapat dilakukan secara optimal dan merata, diperlukan adanya suatu pola pengelolaan pengembangan pariwisata yang kompherhensif, strategis, efisien dan efektif yang menguntungkan semua pemangku kepentingan kelembagaan (Institutional stakeholder), pemerintah daerah, dunia usaha dan masyarakat. Selain itu, mengingat sektor pariwisata sangat multisektoral maka salam perencanaan dan pengelolaan perlu diintegrasikan dalam satu rencana wilayah yang kompherhensif 


\section{TULIP}

\section{TULISAN ILMIAH PARIMISATA}

dimana dalam pelaksanaan membutuhkan komitmen dan dukungan dari semua pihak secara terus-menerus.

Potensi keunikan social-budaya yang dipadu dengan kekhasan alam Toraja memerlukan rencana pengembangan yang mengedepankan dimensi budaya maupun lingkungan dengan berorientasi pada peningkatan ekonomi yang pada gilirannya memajukan kesejahteraan masyarakat menuju masyarakat yang mandiri berkualitas. Untuk memujudkan pengembangan pariwisata yang komprehensif dengan mengandalkan budaya dan lingkungan maka salah satu program prioritas dan langkah strategi berkelanjutan yang perlu diambil adalah melakukan Pengembangan Pariwisata dengan tujuan mengembalikan fungsi dari sejumlah objek wisata yang ada di Papualangi.

Pelaksanaan program pengembangan periwisata ini juga ditetapkan dengan kegiatan-kegiatan yang mendukung dan mulai dilaksanakan sesuai dengan target yang telah ditetapkan. Target waktu juga menjadi masalah bagi pihak Dinas dan pada saat proses pelaksanaan, sehingga hal itu mempengaruhi hasil yang diharapkan. Umumnya objek-objek yang menjadi target pengembangan adalah jaraknya yang jauh sehingga itu juga menjadi kendala dalam merealisasikan program ini. Bidang Pariwisata ini seharusnya menjadi prioritas utama dalam pembangunan, karena ini merupakan potensi daerah yang paling bisa dibanggakan dan bisa meningkatkan PAD guna meningkatkan perekonomian daerah.

Program Pengembangan Pariwisata selalu menjadi prioritas kegiatan Dinas dan merupakan program yang berkesinambungan. Sampai saat ini kondisi yang di ingankan belum menjadi kenyataan seperti yang diharapkan oleh semua pihak, bahkan pihak Dinas juga tidak mampu berbuat banyak dalam melaksanakan apa yang tertera dalam program. Kesenjangan antara kondisi terkini dengan harapan telah diupayakan diminimalisir melalui kebijakan-kebijakan, melihat peranan pariwisata yang begitu strategis serta menopang Pendapatan Asli Daerah (PAD). Dari hasil diskusi yang dilakukan penulis bersama kepala Bagian Pengembangan Pariwisata Papualangi Program Pengembangan Destinasi Wisata

Available Online at http: //journal.umgo.ac.id/index.php/Tulip 


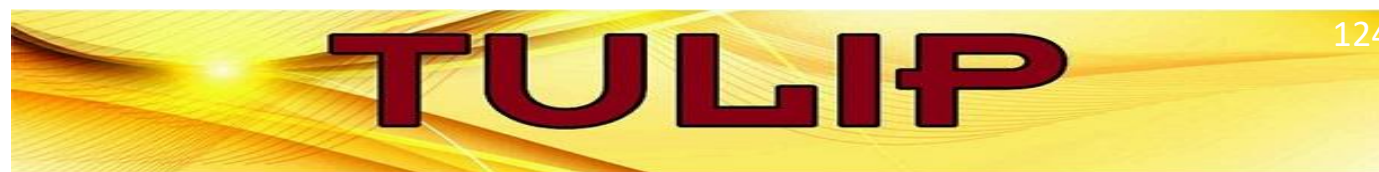

\section{TULISAN ILMIAH PARIMISATA}

1. Penataan Objek Wisata Uggulan

Papualangi sebagai daerah yang terkenal dengan pariwisatanya memang sudah terkenal dengan beberapa objek wisata yang sudah ada sejak lama namun tetap di unggulkan hingga saat ini. dikunjungi wisatawan. Untuk memajukan objek wisata ini, Dinas Kebudayaan dan Pariwisata membuat program untuk penataan peninggalan nenek moyang ini sebagai objek wisata yang lebih baik lagi.

Secara umum keseluruhan kegiatan di atas dalam rangka merealisasikan program tersebut telah di upayakan semampu pihak yang bersangkutan, seperti pembangunan papan petunjuk, toilet dan pagar. Tentunya dengan melihat kondisi yang ada dan keadaan yang diinginkan. Telah diupayakan melalui penetapan sasaran dan kebijakan, namun sangat disayangkan karena ternyata bahwa hal itupun tidak mampu dilakukan secara baik dan konsisten.

Pada saat peneliti mengadakan survei ke beberapa objek wisata yang menjadi sasaran program di atas, ada beberapa yang masih dalam proses perbaikan. kemudian ada yang tidak terawat dengan baik oleh masyarakat yang ada di sekitar objek. Sehingga, kembali lagi bahwa perlu adanya kesadaran individu maupun kelompok masyarakat. Dapat disimpulkan bahwa kegiatan tersebut di atas tidak begitu maksimal, usaha pengembangan daerah tujuan wisata yang dilakukan sesuai dengan kondisi anggaran yang ada. Adapun sedikit usaha untuk memelihara proyek yang telah diselesaikan adalah dengan mengadakan kegiatan kerja bakti untuk menjaga kebersihan objek, namun itu dilakukan pada objek yang jaraknya dekat dengan kantor Dinas.

2. Program Pengembangan Kemitraan

Program pengembangan Kemitraan bertujuan untuk meningkatkan kapasitas SDM (Sumber Daya manusia) pada bidang Kebudayaan dan Pariwisata. Program yang telh dijalankan oleh Dinas kebudayaan dan pariwisata Papualangi yakni :

1. Peningkatan Peran serta masyarakat dalam pengembangan kawasan wisata. Adapun bentuk kegiatan yang dilakukan oleh pihak Dinas 


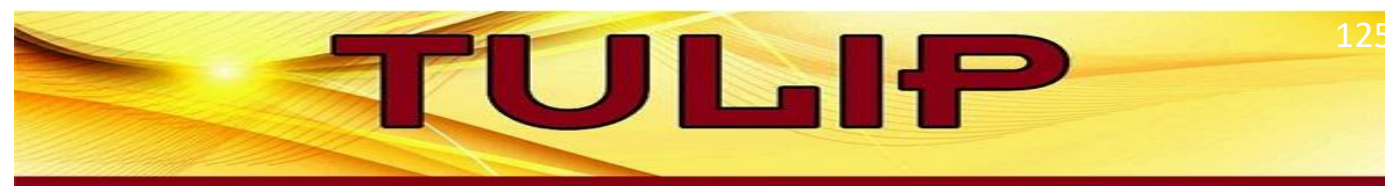

\section{TULISAN ILMIAH PARIMISATA}

Kebudayaan dan Pariwisata Tana Toraja yaitu mengajak masyarakat yang tinggal di lokasi objek wisata untuk ikut berpartisipasi mengembangkan dan melestarikan objek wisata yang ada. Dan bersama-sama dengan pemerintah untuk ikut dalam proses pembangunan fisik dan menjaga kebersihan lingkungan objek wisata. Ini dilakukan dalam bentuk sosialisasi dan kerja bakti di lokasi objek wisata.

2. Pengembangan SDM dan bekerja sama dengan lembaga lainnya.

Adapun lembaga yang dimaksud, yaitu :

1. Swisscontect

2. One Asia

3. Event BBTF (Bali Beyond Travel Fair)

4. Toraja DMO (Destinasi Manajemen Organisasi)

5. Event TIF (Toraja Internasional Festifal)

Adapaun bentuk kegiatan Pengembangan SDM yaitu melaksanakan pelatihan-pelatihan terkait kepariwisataan kepada pegawai Dinas Kebudayaan dan Pariwisata Tana Toraja. Adapun jumlah pegawa yang di ikut sertakan dalam pelatihan adalah 24 orang.

Program Pengembangan Pemasaran Pariwisata

Program pengembangan pemasaran pariwisata dirumuskan dengan tujuan untuk meningkatkan pemasaran yang kreatif, inovatif dan efektif. Pengembangan tersebut kemudian di realisasikan melalui kegitan :

Hasil dan Pembahasan

Evaluasi Program Pengembangan Pariwisata Papualangi

I. Proses

Proses secara khusus merinci berbagai aktivitas yang harus dikerjakan untuk menyelesaikan program-program organisasi. Berbicara mengenai proses yang dilalui guna melaksanakan program pengembangan pariwisata. Proses secara keseleruhan mulai dari perencanaan awal telah berjalan sebagaimana mestinya,

Available Online at http: //journal.umgo.ac.id/index.php/Tulip 


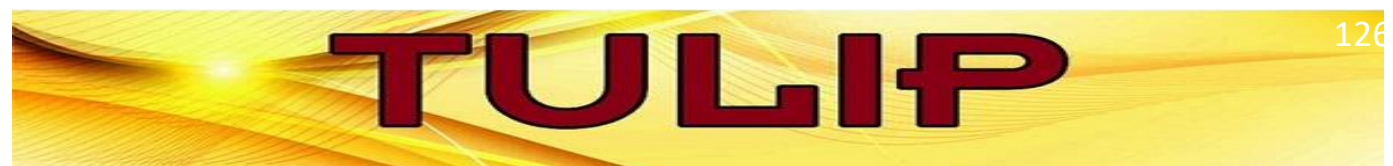

\section{TULISAN ILMIAH PARIMISATA}

yakni melalui musrenbang yang melibatkan para perencana dan tokoh masyarakat sampai kepada penyususnan program dan anggaran yang dibutuhkan. Berikut gambaran proses usulan pelaksanaan program pengembangan pariwisata di Papualangi

Proses pengusulan dan pelaksanaan program kepariwisataan, melalui usulan masyarakat, pemerintah dan sampai kepada penetapan kebijakan dan melalui kebijakan kemudian menghasilkan program. Program dan kegiatan sebagaimana implementasi dari pengembangan pariwisata sudah tercatat dengan baik. Tetapi dalam hal pelaksanaan dilapangan pada kenyataannya tidak lagi sesuai dengan apa yang hendak dicapai sebelumnya. Berdasarkan data sekunder, banyak objek wisata yang sampai saat ini belum tersentuh, utamanya yang jauh dari pusat kota. Pembukaan objek wisata baru selalu ada, namun pengelolaannya sangat disayangkan karena tidak mendapat perhatian yang lebih sehingga mengurangi minat wisatawan untuk berkunjung, khususnya wisatawan lokal karena rute yang harus dilalui dalam kondisi rusak dan hanya dapat ditempuh dengan berjalan kaki.

Memang benar apa yang dikatakan oleh kepala Dinas, saat penulis berkeliling di beberapa lokasi di Papualangi, pelebaran jalan masih dalam tahap perbaikan. Penulis melihat proses pengerjaan tergolong lamban, pelebaran jalan yang sudah dari tahun ke tahun telah direncanakan sampai saat ini belum selesai. Penulis melihat dipinggir jalan hanya ada beberapa pekerja dan tumpukan batubatu gunung dan pasir sehingga terkadang membuat kemacetan. Kemudian bandara pongtiku yang juga penulis kunjungi, lokasi yang cukup jauh dari pusat kota dan bandara belum beroperasi secara maksimal. Sehingga penulis dapat menarik kesimpulan bahwa memang program ini mempunyai tujuan yang sangat jelas tetapi pada pencapaiannya masih sangat kurang.

\section{Manfaat}




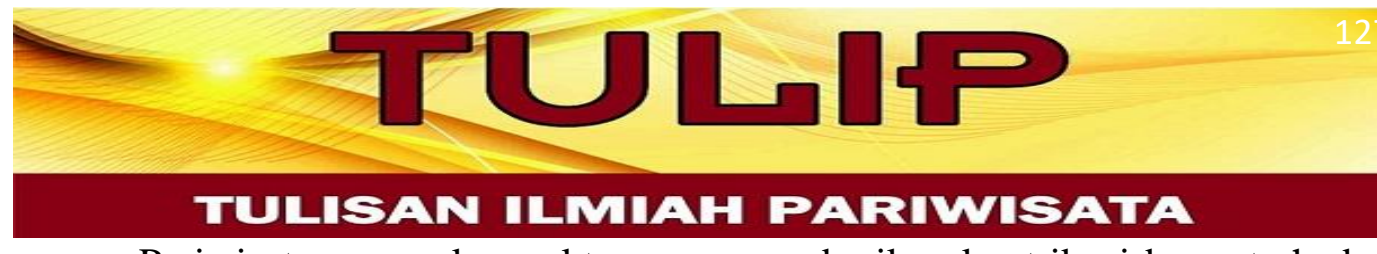

Pariwisata merupakan sektor yang memberikan kontribusi besar terhadap perekonomian. Untuk dapat menjadikan sektor ini berhasil, maka diperlukan kepandaian dalam mengelola aset pariwisata yang ada, kekayaan alam dan budaya. Keberhasilan kepariwisataan tidak hanya menjadikan target utama menarik wisatawan asing untuk datang, tetapi juga untuk mengembangkan peluang usaha-usaha masyarakat di dalamnya untuk berkembang

Usaha-usaha pengembangan pariwisata yang berorientasi pada masyarakat lokal masih kurang. Secara sederhana, partisipasi merupakan sebuah proses dimana masyarakat sebagai stakeholders, terlibat mempengaruhi dan mengendalikan pembangunan pariwisata. Dengan cara demikian potensi yang dimiliki dapat dikembangkan sebagai aktivitas perekonomian dalam membangun kepariwisataan menjadi sesuatu yang bermanfaat.

\section{PENUTUP}

Berdasarkan hasil penelitian dan pembahasan yang telah disusun oleh penulis, maka dapat disimpulkan bahwa, Keterpengaruhan Komponen Pariwisata Didaya Tarik Pariwisata Arung Jeram Papualangi telah berjalan sesuai dengan sistem yang ada, namun terdapat masalah-masalah yang membawa dampak negatif sehingga pada pelaksanaannya masih belum optimal dalam mengembangkan pariwisata Arung Jeram Papualangi. Pada target pelaksanaan juga belum terselesaikan sesuai dengan target yang ditetapkan. Perhatian, komitmen, dana, lokasi dan waktu menjadi masalah pada saat proses pelaksanaan, sehingga hal itu mempengaruhi hasil yang diharapkan.

Available Online at http: //journal.umgo.ac.id/index.php/Tulip 


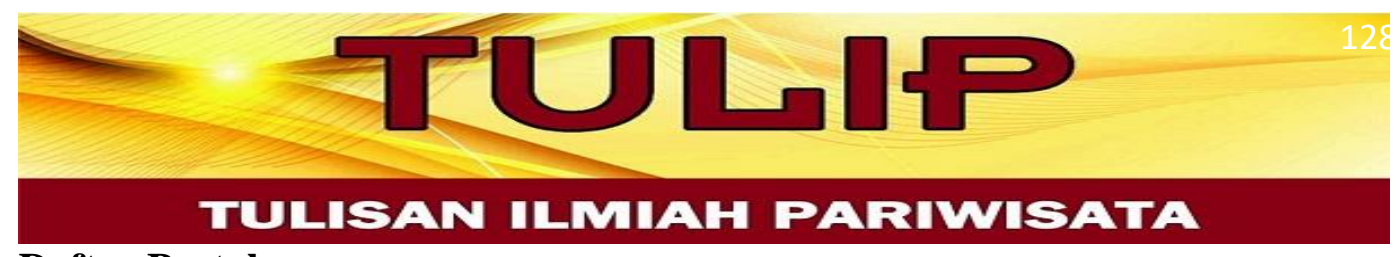

\section{Daftar Pustaka}

Djuju, Sdjuna. 2006. Evaluasi Program Pendidikan Luar Sekolah ; Untuk Pendidikan Non Formal dan Pengembangan Sumber Daya Manusia.

Bandung : Falah Production.

Dwijowijito, Nugroho. 2003. Kebijakan Publik ; Formulasi, Implementasi dan

Evaluasi. Jakarta : PT Elex Media Komputindo.

Frank, Gerald, Mara. 2015. Handbook Analisis Kebijakan Publik ; Teori,

Politik dan Metode. Bandung : Nusa Media.

Ibrahim, Amin. 2009. Pokok-pokok Administrasi publik dan

Implementasinya.

Bandung : PT. Refika Aditama.

Kartasasmita, Ginandjar. 1997. Administrasi Pembangunan ; Perkembangan

Pemikiran dan Praktiknya di Indonesia. Jakarta: PT. Pustaka LP3ES.

Katz, Saul. 1992. Modernisasi Administrasi Untuk Pembangunan Nasional.

Jakarta : PT. Rineka Cipta.

Moekijat. 1995. Analisis Kebijaksanaan Publik. Bandung : CV Mandar maju.

Nugroho, Iwan. 2011. Ekowisata dan Pembangunan berkelanjutan.

Yogyakarta: Pustaka Pelajar.

Oemar, Hamalik. 2003. Proses Belajar Mengajar. Jakarta : PT. Bumi Aksara.

Siagian, Sondang. 2007. Administrasi Pembangunan ; Konsep,

Dimensi, dan Strateginya. Jakarta: PT. Bumi Aksara.

Subarsono. 2006. Analisis Kebijakan Publik ; Konsep, Teori dan Aplikasi.

Yogyakarta: Pustaka Pelajar.

Surwantoro, Gamal. 2004. Dasar-dasar Pariwisata. Yogyakarta : Andi Offset.

Tjokroamidjojo, Bintoro. 1995. Perencanaan Pembangunan. Jakarta :

PT. Toko Gunung Agung.

Yoeti, Oka. 2006. Tours and Travel Marketing. Jakarta : PT Pradnya Paramita.

Parsons, Wayne. 2005. Public Policy ; Pengantar Teori dan Praktik

Analisis Kebijakan. Jakarta: Kencana Prenada Media Group.

Available Online at http://journal.umgo.ac.id/index.php/Tulip 


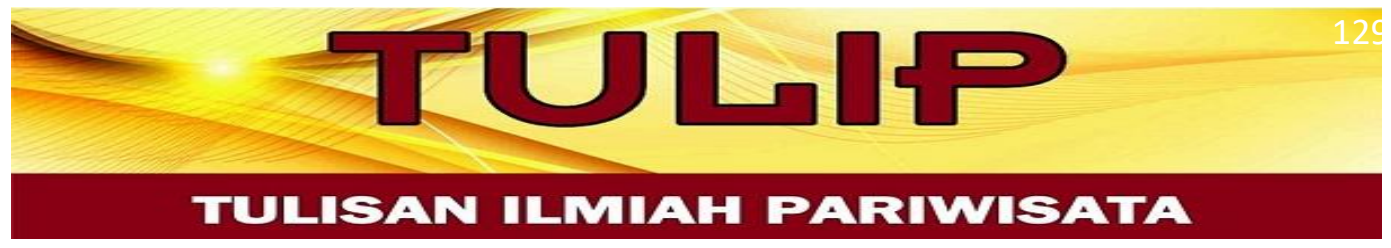

Pitana, Gayatri. 2005. Sosiologi Pariwisata. Yogyakarta : Andi Offset. Umar.

Husein. 2005. Evaluasi Kinerja Perusahaan. Jakarta : PT Gramedia

Pustaka Utama

Wirawan. 2012. Evaluasi ; Teori, Model, Standar, Aplikasi dan Profesi. Jakarta: PT Rajagrafindo Persada. 